\title{
1 A Sr-Nd-Hf isotope characterization of dust source areas in Victoria Land and the 2 McMurdo Sound sector of Antarctica
}

4 Molly A. Blakowski ${ }^{1 *}$, Sarah M. Aciego ${ }^{1}$, Barbara Delmonte ${ }^{2}$, Carlo Baroni ${ }^{3}$, Maria Cristina

5 Salvatore ${ }^{3}$, Kenneth W. W. Sims ${ }^{4}$

${ }^{1}$ Department of Earth and Environmental Sciences, University of Michigan, 1100 N. University

8 Avenue, Ann Arbor, MI 48109-1005; ${ }^{2}$ DISAT, University of Milano- Bicocca, Piazza della

9 Scienza n. 1, 20126, Milan, Italy; ${ }^{3}$ Dipartimento di Scienze della Terra, University of Pisa, Via

10 S. Maria n. 53, 56126, Pisa, and CNR, Instituto di Geoscienze e Georisore, Pisa Italy;

$11{ }^{4}$ Department of Geology and Geophysics, University of Wyoming, 1000 E. University Avenue,

12 Laramie, WY 82071-2000

14 *Corresponding author: mollybla@umich.edu

Keywords

17 Dust; Sr-Nd isotopes; Nd-Hf isotopes; Antarctica; paleoclimate

\section{Abstract}

20 Determining the geographical provenance of dust provides crucial insight into the global dust

21 cycle. For the East Antarctic Ice Sheet (EAIS), the importance of Southern hemisphere potential

22 dust sources has been thoroughly investigated using radiogenic isotopes, whereas proximal dust

23 source areas located on the periphery of the ice sheet remain poorly documented from a

24 geochemical standpoint. In this work, we expand the existing isotopic ( $\mathrm{Sr}-\mathrm{Nd}$ ) catalogue of dust

25 and sand-sized sediments from Victoria Land and the McMurdo Sound sector, and incorporate

26 Hf isotopic data to place additional constraints on dust source identification. The isotopic field

27 for materials considered in this study is characterized by ${ }^{87} \mathrm{Sr} r{ }^{86} \mathrm{Sr}$ ratios ranging from 0.703 to

280.783 , $\varepsilon \mathrm{Nd}$ between -12.01 and 6.36 , and $\varepsilon \mathrm{Hf}$ from -16.77 to 6.89 . As reported in previous

29 works, the data reveal close relationships between Antarctic sediments and distinct parent

30 lithologies; in addition, our findings emphasize the background presence of very fine dusts

31 originating from dominant global sources and regional volcanic activity as barriers to direct 
32 source-to-sink comparison of isotopic signatures. Thus, geochemical characterizations of dust

33 sources to the Antarctic ice sheet involving multiple size fractions, including coarser-grained

34 particles more susceptible to short-range transport, can help us to rule out global sources of dust

35 when examining local sediment cores and ice cores.

\section{Introduction}

Eolian dust preserved in polar ice cores is an important indicator of past climatic conditions in the continents and the evolution of paleo-atmospheric circulation patterns (Basile et al., 1997; Biscaye et al., 1997; Bory et al., 2010; Bory et al., 2002; Bory et al., 2003; Delmonte et al., 2008; Delmonte et al., 2010; Delmonte et al., 2013; Delmonte et al., 2004a; Delmonte et al., 2004b; Delmonte et al., 2007; Gaiero, 2007; Grousset and Biscaye, 2005; Grousset et al., 1992; Marino et al., 2008); understanding the geographic provenance of ice core dust in particular has become important for informing global circulation models and deciphering past environmental conditions of the surrounding landmasses (e.g. Bory et al., 2003; Gabrielli et al., 2010; Mahowald et al., 1999; Mahowald et al., 2006; Svensson et al., 2000). Grounded on the rationale that sediments and soils derived from rocks of different lithologies and geologic ages tend to maintain the radiogenic isotope compositions (or "fingerprints") of the rocks from which they were eroded, dust provenance can be determined by comparing the geochemical compositions of dust particles preserved in undisturbed sequences of snow and ice to the fingerprints of fine-grained sediments collected from target potential sources areas (PSA) (e.g. Grousset and Biscaye, 2005). In this way, it has been determined that southern South America (SSA) was likely the dominant supplier of dust to the entire East Antarctic Ice Sheet (EAIS) during the Last Glacial Maximum (LGM) (e.g. Delmonte et al., 2008; Delmonte et al., 2010; Delmonte et al., 2013; Delmonte et al., 2004a; and EPICA-Dome C) have been matched with SSA source areas for glacial times (Basile et al., 1997; Delmonte et al., 2004a; Gaiero, 2007; Revel-Rolland et al., 2006; Sugden et al., 2009),

60 little information exists on the origin of eolian dusts and sediments preserved in these ice cores

61 for interglacials such as the Holocene (Delmonte et al., 2010; Delmonte et al., 2013). Numerous

62 studies have suggested that ice-free areas located at the present-day margin of the EAIS could be 
63 important generators of mineral material (dust, sediments), and yet limited data exists for these

64 PSAs (e.g. Lanci et al., 2008; Vallelonga et al., 2010); in contrast to the cores drilled further

65 inland, coastal ice cores TALDICE-Talos Dome and Taylor Dome may be especially influenced

66 by local dust sources due to their proximity (see Figure 1).

67 In this work, we sought to deepen the current understanding of Holocene dust input to the 68 periphery of the EAIS by expanding the existing geochemical catalogue of local Antarctic PSAs.

69 Windborne dust derived from remote continental sources and deposited in Antarctic ice cores

70 typically consists of particles smaller than $<5 \mu \mathrm{m}$ (diameter) (Gaiero, 2007; Lupker et al., 2010);

71 however, contribution from local sources may include all size bins (i.e. larger particle diameters),

72 which is why we chose to separately analyze a $<5 \mu \mathrm{m}$ (fine fraction) sample and a bulk sediment

73 sample from each PSA. Considering both the grain size and isotopic composition of a PSA

74 sample may help determine whether the sampling site represents primary or secondary source of

75 dust (Delmonte et al., 2004a). In this same way, combining and comparing data from multiple

76 isotope tracer systems greatly improves the chances of distinguishing PSA samples that have

77 been weathered directly from a local deposit (e.g. moraine) from samples composed of a mixture

78 of particles that have already been subject to eolian or fluvial transport. Here, we characterize an

79 array of primary and secondary dust sources concentrated at the margin of the Antarctic ice sheet

80 using the $\mathrm{Sm}-\mathrm{Nd}, \mathrm{Rb}-\mathrm{Sr}$, and $\mathrm{Hf}-\mathrm{Lu}$ isotope systems in order to gain a more thorough

81 understanding of regional dust provenance and transport pathways, and expand the pre-existing

82 catalogue of southern hemisphere PSAs.

83 Investigations of $\mathrm{Sr}$ compositions in sediments of differing particle sizes began with

84 Dasch's pioneering work (1969) on the behavior of Sr in weathering profiles, deep-sea

85 sediments, and sedimentary rock, wherein it was observed that ${ }^{87} \mathrm{Sr} /{ }^{86} \mathrm{Sr}$ ratios tend to increase

86 with decreasing grain size. In recent years, a number of studies have expanded upon grain size

87 controls on ${ }^{87} \mathrm{Sr} /{ }^{86} \mathrm{Sr}$ in various sediments, including deep-sea NE Atlantic sediments (Meyer et

88 al., 2011) and Asian dust (Kanayama et al., 2005). Similar to ${ }^{87} \mathrm{Sr} /{ }^{86} \mathrm{Sr},{ }^{143} \mathrm{Nd} /{ }^{144} \mathrm{Nd}$ ratios of

89 weathered dust are often studied and compared to compositions of corresponding source rock

90 material (e.g. Basile et al., 1997; Bory et al., 2010; Delmonte et al., 2004a; Gaiero, 2007;

91 Grousset et al., 1992). For instance, Feng et al. (2011) analyzed the $\mathrm{Sr}$ and Nd isotopic

92 compositions of Chinese loess and dust-fall samples in seven different grain-size fractions, and

93 found that $\varepsilon N d$ values for homogenous samples varied little between the size fractions. Similar 
94 results have been reported in works by Grousset et al. (1992), Kanayama et al. (2005), Chen et 95 al. (2007), and Meyer et al. (2011), to name a few.

Many works to date have also discussed the decoupling of Lu-Hf and Sm-Nd isotope systems in relation to continental weathering and sediment transport (e.g. Aarons et al., 2013;

98 Bayon et al., 2009; Bayon et al., 2006; Carpentier et al., 2009; Garçon et al., 2013; Patchett and 99 Tatsumoto, 1981; Piotrowski et al., 2000; van de Flierdt et al., 2007; Zhao et al., 2014). That is,

100 while the two systems are closely coupled during magmatic processes and remain isotopically

101 linked in whole rock and coarse sediment samples, forming a strong positive correlation known 102 as the "terrestrial array" (Vervoort et al., 1999), the long-term alteration, erosion, and transport 103 of crustal materials can lead to the gravitational separation of dense accessory mineral phases

104 during transport, and therefore an eventual offset between the isotopic signatures of coarse105 grained detrital sediments (i.e. sands) and finer-grained or clay-sized particles (i.e. dusts). If the 106 mineral zircon $\left(\mathrm{ZrSiO}_{4}\right)$ is considered the main reservoir for $\mathrm{Hf}$ and $\mathrm{Zr}$ in terrestrial rocks, a 107 significant variation in the quantity of zircons present in a sediment sample will modify the $108 \varepsilon \mathrm{Hf} / \varepsilon \mathrm{Nd}$ ratio, a phenomenon known as the "zircon effect" (e.g. Carpentier et al., 2009). Zircon 109 grains are very high-density (not easily-transportable by wind), and contain large amounts of 110 non-radiogenic $\mathrm{Hf}$ due to low initial $\mathrm{Lu} / \mathrm{Hf}$ ratios and the slow radiogenic decay of ${ }^{176} \mathrm{Lu}$ to ${ }^{176} \mathrm{Hf}$ 111 (Patchett and Tatsumoto, 1981). Thus, it can be generalized that the continental (non-marine) 112 budget of Hf is effectively split between (1) a low $\varepsilon H f$ reservoir in zircon-bearing sediments, and 113 (2) a more radiogenic, zircon-free reservoir (Bayon et al., 2009; Carpentier et al., 2009). Although it may not necessarily be possible to pinpoint the exact nature of a PSA sample 115 due to mixing of proximal and remote sources, the unique physical and isotopic properties of 116 materials featured in this study have allowed us to narrow down and characterize a number of 117 potential dust sources to snow and ice layers located at the periphery of the EAIS, including: the 118 McMurdo Sound (MS) volcanics and glacial drifts; the Northern Victoria Land (NVL) regoliths, 119 and; the regoliths, drifts, and sands of Southern Victoria Land's (SVL) dry valleys, including the 120 Taylor Valley moraines (Figure 3).

\section{2. Regional setting}

123 Virtually the entire Antarctic continent is covered by ice year round, with the exception of the 124 ice-free valleys and nunataks of Victoria Land and the nearby McMurdo Sound/Ross Sea sector, 
125 located along the north-central extent of the Transantarctic Mountains (TAM) (see Figure 1

126 inset). Here, freezing temperatures, hyper-arid conditions, and distinctive daylight cycles result

127 in a diverse array of erosional and depositional landforms, most of which are characterized by

128 underdeveloped soils or loose, unconsolidated material (Delmonte et al., 2013). Equally diverse

129 is the local bedrock, ranging from Late Proterozoic-to-early Paleozoic granites and gneisses,

130 Devonian-to-Triassic Beacon Supergroup sedimentary rocks, and sills of the Jurassic Ferrar

131 dolerite (e.g. Stump and Fitzgerald, 1992). Below, we describe the three general regions from

132 which the PSA samples discussed in this work were obtained, with additional geographic

133 information summarized in Table 1 of the supplementary material.

\subsection{Northern Victoria Land}

136 Northern Victoria Land (NVL) is bounded by the Borchgrevink Coast (the western margin of the

137 Ross Sea), the Rennick Glacier basin to the west, and the Pennel Coast (Pacific Ocean) to the 138 north (Baroni et al., 2005b). Previous surface exposure dating studies conducted in Victoria Land 139 have revealed that relict surfaces in NVL document a continuous and long lasting (millions of 140 years) exposure to wind erosion (Armienti and Baroni, 1999; Di Nicola et al., 2012; Di Nicola et 141 al., 2009; Oberholzer et al., 2008; Oberholzer et al., 2003; Schäfer et al., 1999; Strasky et al.,

142 2009; Summerfield et al., 1999). Delmonte et al. (2010) suggested that mineral particles derived

143 from the Mesa Range and other high-altitude ice-free areas of NVL may be favored for transport 144 inland during times when maritime air masses sweep across the Antarctic plateau.

\subsection{Southern Victoria Land}

147 The McMurdo Dry Valleys (MDV) of Southern Victoria Land (SVL) are a series of east-west 148 oriented, ice-free valleys carved by retreating glaciers, and make up the largest ice-free area in 149 Antarctica (Fountain et al., 1999; Marchant and Head, 2007). Air flows seaward from the Polar

150 Plateau and is forced over the TAM, cooling, condensing, and falling as snow at high elevations, 151 a phenomenon that casts the intense rain-shadow to which the MDV owes its extreme aridity and 152 winds (Fountain et al., 1999). The valley floors are covered with rocks and sediments from the 153 Beacon Supergroup, as well as from older granites and gneisses of the Ross Orogeny. Although 154 sandy deposits are found throughout the MDV, the only areas where major eolian sand 155 accumulates are within the Victoria Valley, near the hypersaline Lake Vida and the Victoria 
156 Lower Glacier (Selby et al., 1974). Here, windblown materials have accumulated into a series of

157 transverse and whaleback dunes (Selby et al., 1974).

\subsection{McMurdo Sound}

160 Numerous PSA samples were collected from the low-elevation, coastal area inland of the Ross

161 Sea, bounded by the MDV and the Polar Plateau, the McMurdo Ice Shelf extending to McMurdo

162 Sound, and Ross Island; we hereafter refer to this region as the McMurdo Sound sector (MS).

163 This area — specifically Ross Island - is home to Mt. Erebus, an active composite volcano from

164 which about $4520 \mathrm{~km}^{3}$ of volcanic material has erupted over the past $\sim 4 \mathrm{Ma}$ (Esser et al., 2004).

165 Because the MS geology is dominated by Late Cenozoic, alkaline volcanics belonging to the

166 McMurdo Volcanic Group (Kyle et al., 1990; Sims et al., 2008), a relatively straightforward

167 geochemical distinction was anticipated between MS PSAs closer to Mt. Erebus and the Victoria

168 Land PSAs.

169

170 3. Materials and methods

\section{$171 \quad 3.1$ Sample collection}

172 Closely following the sampling strategies described in Delmonte et al. (2013) (as well as

173 previous works by these authors), sediments were collected just below the surficial deflation

174 eolic pavement $(1-3 \mathrm{~cm})$, with the collection campaign primarily centered around finding high-

175 elevation sites (including old glacial deposits and relict rock surfaces with well-developed

176 regolith) that could represent sources for loose sediments available for wind transport. Locating

177 many of these potential sites was made possible by previous geological and geomorphological

178 studies carried out in the Victoria Land area over the last decades (Armienti and Baroni, 1999;

179 Baroni et al., 2005a; Baroni et al., 2008; Baroni et al., 2004; Baroni et al., 2005b; Hall and

180 Denton, 2000a, b; Meneghel et al., 1999; Orombelli, 1990; Sugden and Denton, 2004; Sugden et

181 al., 1999; Summerfield et al., 1999). The authors collected additional samples from glacial

182 deposits of various ages, and at elevations ranging from the sea level to more than 2000 m.a.s.1.

183 In SVL, some PSA samples were collected with the assistance of B. L. Hall (glacial deposits)

184 and P. Augustinus (dune sand). Below, we describe the PSA samples analyzed in this work, with

185 further geographic information provided in Table 1 of the supplementary material. 
Two regolith samples were obtained from Frontier Mountain, a large nunatak situated at the inland catchment of the upper Rennick Glacier, near the edge of the Polar Plateau (Perchiazzi et al., 1999). This area is characterized by strong katabatic winds and abundant scattered fragments of local granitoids, pegmatites, and aplites associated with the Granite Harbor Intrusive Complex (Ordovician) (Gunn and Warren, 1962; Perchiazzi et al., 1999). Samples were collected from elevations 2200 and 2700 m.a.s.1., and appear to be directly weathered from the

192 local granites. An additional granitic regolith was collected from the Lichen Hills, about $60 \mathrm{~km}$ 193 southeast of Frontier Mountain.

To the east, two regoliths were sampled from Mount Masley of Pain Mesa, where the 195 local bedrock is dominated by flat layers of Kirkpatrick basalt and intrusions of the Jurassic 196 Ferrar dolerite (Baroni et al., 2004; Baroni et al., 2005b; Mensing and Faure, 1996). The Mesa 197 Range is series of flat-topped, scree-covered mesas located at the head of the Rennick Glacier 198 (Mensing and Faure, 1996). These samples were collected from 2520 and 2533 m.a.s.1., the first 199 of which consists of topsoil on top of regolith, the second of weathered dolerite. A set of four 200 samples was also collected from the Vantage Hills area, approximately $50 \mathrm{~km}$ south of Pain 201 Mesa, nearer the edge of the Polar Plateau. Three of these samples consist of regolith weathered 202 from continental feldspathic sandstone of the Beacon Supergroup, while the southernmost 203 regolith is composed of a metamorphosed version of this sandstone (Capponi et al., 1997;

204 Carmignani, 1989). The fourth sample from the Vantage Hills contains a mixture of glacial drift 205 materials. Finally, two regolith samples were collected from the nearby Illusion Hills and 206 Intermediate Hills, both weathered from the Ferrar dolerite.

207 Courtesy of P. Augustinus, two sediment samples were selected from the dune fields 208 adjacent to Lake Vida, both of which are weathered from the continental sandstone (Bristow et 209 al., 2010a; Bristow et al., 2010b). With the assistance of B. L. Hall, three additional samples 210 were selected from an area slightly south of the dune fields: the first was obtained from an 211 elevation of 1350 m.a.s.l., and consists of older glacial drift material varying from clast212 supported to matrix-supported diamicton with a sandy-silty matrix (Baroni et al., 2008;

213 Delmonte et al., 2010); the next sample is represented by a sandy-silt matrix from LGM glacial 214 drift (correlated to the "Ross Sea I" glaciation, also referred to as the Terra Nova Drift by Baroni 215 and Orombelli (1991)), along with older glacial drift material perhaps from the early- to mid216 Pleistocene (Hall and Denton, 2000b; Kelly et al., 2002), and was collected much nearer sea- 
217 level at 283 m.a.s.l.. A final sample from this set consists of regolith and thin topsoil, a mixture

218 of dolerite fragments with possible traces of Beacon sandstone (1000 $\mathrm{m}$ a.s.1.).

219 From Taylor Valley, the southernmost of the ice-free valleys, five additional sediment

220 glacial drift samples were collected. The first sample was obtained from one of the Marr Glacier

221 moraines at 754 m.a.s.l. East of the Marr, two samples were gathered from a large moraine

222 composite near the Goldman Glacier and Goldman Ponds, both from around 370 m.a.s.l. The

223 two final samples were collected from a large, very old Taylor Glacier moraine, the second of

224 which appears to be basalt-rich and possibly influenced by old Ross Sea drift; these were

225 sampled at 420 and 438 m.a.s.l., respectively (Denton et al., 1993; Hall et al., 1993; Sugden and

226 Denton, 2004).

227 Two regolith samples were collected from Tent Island (Erebus Bay) and Knob Point: a

228 porphyric phonolite and an olivine basalt with xenolithic inclusions. Next, a total of seven glacial

229 drift samples identified as LGM Ross Sea Drift (Hall and Denton, 2000a; Stuiver et al., 1981)

230 were obtained from a variety of sampling sites, all within fairly close proximity to one another.

231 These sites are as follows: Bratina Island; Dailey Island; Walcott Bay; Gneiss Point; Cape

232 Crozier (Ross Island), and Cape Crozier's Bomb Peak (Ross Island). Six samples were from

233 Cape Bird, including a volcanic regolith, additional Ross Sea Drift materials from the LGM

234 (these potentially containing volcanic scoria or glasses), and two samples from a Holocene ice-

235 cored moraine. The final MS site, Cape Royds, provided two regolith/drift samples composed of

236 porphiric phonolite and volcanic scoria, as well as one ash sample.

\section{$238 \quad 3.2$ Sample preparation and dissolution}

239 Samples were prepared for isotopic analysis in a 10,000 level clean room at the University of

240 Michigan, inside class 10 laminar flow hoods. Fine fraction PSA samples (particle size $<5 \mu \mathrm{m}$ )

241 were selected according to separation procedures outlined in Delmonte et al. (2004a) at the

242 Univeristy of Milano-Biocca, and checked using a Laser Particle Counter. Once separated, the

243 dusts (approximately $10 \mathrm{mg}$ of sample for either grain size fraction) were weighed into $3 \mathrm{~mL}$

244 Teflon beakers in preparation for Parr bomb digestion.

245 It has been demonstrated that standard hot plate digestion procedures using concentrated

246 acids do not guarantee the complete dissolution of whole-rock samples containing refractory

247 minerals such as zircon and garnet (Blichert-Toft et al., 2004; Mahlen et al., 2008; Patchett and 
Tatsumoto, 1981). Because these same minerals tend to be highly concentrated in hafnium (Hf),

249 an incomplete digestion of a sample could skew $\mathrm{Hf}$ concentrations and ${ }^{176} \mathrm{Hf} /{ }^{177} \mathrm{Hf}$ ratios, thereby

250 excluding the application of the Lu-Hf isotope system from the work. In this study, following the

251 advice of Patchett and Tatsumoto (1981) and many others (e.g. Blichert-Toft et al., 2004; Lapen

252 et al., 2004; Mahlen et al., 2008), all samples were dissolved in highly pressurized, steel-jacketed

253 Parr bombs using a two-phase acid attack. Once dissolved, the column chemistry procedures

254 established by Aciego et al. (2009) were used to isolate the elements Sr, Nd, and $\mathrm{Hf}$ for isotopic

255 analyses.

\subsection{Neodymium isotope analysis}

258 The initial-stage column, filled with 50-100 $\mu \mathrm{m}$ mesh TruSpec resin, split each sample into three 259 cuts, of which the second cut containing the high field strength elements (HFSE) and the rare 260 earth elements (REE) was set aside for subsequent sets of Nd chemistry. First, columns loaded 261 with 100-200 $\mu \mathrm{m}$ LnSpec resin were used to separate the REEs from the HFSE, including Hf. 262 Then, in the second separation stage, REE cuts were loaded into columns containing 50-100 $\mu \mathrm{m}$ 263 LnSpec resin and exposed to a sequence of hydrochloric acids of varying normality in order to 264 isolate the $\mathrm{Nd}$, described in greater detail by Aciego et al. (2009).

Once dried, $1 \mu \mathrm{L}$ each of $3 \mathrm{M} \mathrm{HCl}$ and $3 \mathrm{M} \mathrm{HNO}_{3}$ was added to the sample, and the solutions were loaded onto outgassed rhenium double filaments. A current of 0.8 A was run 267 through the filament until the sample dried. The current was then increased to 1.8 A and held for 26860 seconds, after which it was briefly flashed at $2.2 \mathrm{~A}$ before returning to $0 \mathrm{~A}$. Isotopic ratios 269 were measured at the Glaciochemistry and Isotope Geochemistry Laboratory at the University of 270 Michigan using a Thermo Scientific Triton PLUS Thermal Ionization Mass Spectrometer 271 (TIMS), following methods detailed by Aarons et al. (2013). To correct for mass fractionation, $272 \mathrm{Nd}$ was normalized to ${ }^{146} \mathrm{Nd} /{ }^{144} \mathrm{Nd}=0.7129$, and mass 149 was monitored for Sm interference. 273 The Nd isotopic standard JNdi-1 (10 ng) was measured to be ${ }^{143} \mathrm{Nd} /{ }^{144} \mathrm{Nd}=0.5121008(2 \sigma= \pm$ $\left.2742.37601 \times 10^{-5}\right)$. During the course of this study, the BCR-2 USGS basalt rock standard yielded a $275{ }^{143} \mathrm{Nd} /{ }^{144} \mathrm{Nd}$ ratio of $0.512625\left(2 \sigma= \pm 1.41174 \times 10^{-5}\right)$, and measured blanks were considered to be 276 negligible. Below, Nd compositions are reported in terms of their deviations from the Chondritic 277 Uniform Reservoir (CHUR) evolution line, wherein $\varepsilon \mathrm{Nd}(0)=$ 
$278\left(\left({ }^{143} \mathrm{Nd} /{ }^{144} \mathrm{Nd}\right)_{\text {meas }} /\left({ }^{143} \mathrm{Nd} /{ }^{144} \mathrm{Nd}\right)_{\mathrm{CHUR}}\right)-1 \times 10^{4}$, using the present-day CHUR value of 0.512638

279 (Jacobsen and Wasserburg, 1980).

\subsection{Strontium isotope analysis}

282 The first set of the three TruSpec cuts, containing the $\mathrm{Sr}, \mathrm{Pb}$, and $\mathrm{Ra}$ fractions was dried down and brought up in $7.5 \mathrm{M} \mathrm{HNO}_{3}$. Samples in solution were subsequently loaded into columns filled with 50-100 m mesh Eichrom Strontium Spec resin, and processed according to the recipe dictated by Aciego et al. (2009).

The dried strontium samples were re-dissolved in $1 \mu \mathrm{L}$ of $7.5 \mathrm{M} \mathrm{HNO}$, and loaded mixed with $0.8 \mu \mathrm{L}$ of TaF5 activator onto outgassed rhenium single filaments to enhance ionization efficiency (Charlier et al., 2006). Drying procedures resembled those previously described for $\mathrm{Nd}$, with samples heated and left to dry down at a current of $0.8 \mathrm{~A}$, followed by a brief flash to 2.2 A. Radiogenic Sr isotopic ratios were then measured on the University of Michigan TIMS, following methods described by Stevenson et al. (2014). All measurements were corrected for mass fractionation using ${ }^{86} \mathrm{Sr} /{ }^{88} \mathrm{Sr}=0.1194$. The isotopic standard NBS-SRM-987 yielded a value of ${ }^{87} \mathrm{Sr} /{ }^{86} \mathrm{Sr}=0.710291\left(2 \sigma= \pm 8 \times 10^{-6}\right)$, and the USGS reference material BCR-2 measured ${ }^{87} \mathrm{Sr} /{ }^{86} \mathrm{Sr}=0.705033\left(2 \sigma= \pm 7.86 \times 10^{-6}\right)$, in good agreement with reported literature values (e.g.

295 Aarons et al., 2013; Aciego et al., 2009).

\subsection{Hafnium radiogenic isotope analyses}

298 Hf, along with the other HFSEs, was separated from the REEs during Nd column chemistry; Hf cuts were passed through an additional $\mathrm{LnSpec}$ column to isolate from the elements $\mathrm{Lu}, \mathrm{Yb}$, and $\mathrm{W}$ to prevent isobaric interferences. After this stage, samples were dried down and transferred to the University of Wyoming's High-Precision Isotope Laboratory, where they were brought up in $1 \mathrm{M} \mathrm{HNO}_{3}$ and measured on a Thermo Scientific Neptune Plus Multiple Collector Inductively Coupled Plasma Mass Spectrometer (MC-ICP-MS) as detailed in Arendt et al. (2014). During analysis, instrumental mass fractionation was corrected using ${ }^{179} \mathrm{Hf} /{ }^{177} \mathrm{Hf}=0.7325$ and the exponential fractionation law and masses 182, 175, and 172 were monitored for $\mathrm{W}, \mathrm{Lu}$ and $\mathrm{Yb}$ interferences. Baselines were measured prior to each sample, and amplifier gains were measured at the start of every day. Interference corrections to ${ }^{176} \mathrm{Hf} /{ }^{177} \mathrm{Hf}$ were less than $100 \mathrm{ppm}$. All 
309 reference material (accepted value of ${ }^{176} \mathrm{Hf} /{ }^{177} \mathrm{Hf}=0.28216$ ) (Vervoort and Blichert-Toft, 1999).

310 Hf isotopic compositions obtained for the BCR-2 rock standard measured ${ }^{176} \mathrm{Hf} /{ }^{177} \mathrm{Hf}=0.28288$

$311\left(2 \sigma= \pm 4 \times 10^{-5}\right)$, similar to reported literature values (e.g. Jweda et al., 2015). As with Nd, Hf

312 isotope ratios will throughout the text be presented in epsilon notation, with $\varepsilon \mathrm{Hf}(0)=$

$313\left(\left({ }^{176} \mathrm{Hf} /{ }^{177} \mathrm{Hf}\right)_{\text {meas }} /\left({ }^{176} \mathrm{Hf} /{ }^{177} \mathrm{Hf}\right)_{\mathrm{CHUR}}\right)-1 \times 10^{4}$, wherein CHUR = 0.282785 (Nowell et al., 1998).

\section{3. Results}

316 The isotopic compositions of fine $(<5 \mu \mathrm{m})$ and bulk fraction PSA samples analyzed in this work 317 are reported in Table 1 of the supplementary material. New Sr-Nd fingerprints plot along the 318 same "hyperbolic envelope" as previously measured Victoria Land PSA data (Delmonte et al., 319 2010; Delmonte et al., 2013), which have been shaded in gray and plotted along with the new 320 data in Figure 2 (samples measured by Delmonte and coworkers were measured exclusively in

321 the finer $(<5 \mu \mathrm{m})$ grain size fraction). Also included in Figure 2 are the $\mathrm{Sr}-\mathrm{Nd}$ isotopic

322 compositions of lava and tephra samples from Erebus volcano (Sims et al., 2008), grouped in 323 color along with our "McMurdo Volcanics/glacial drift" samples based on close isotopic 324 similarities.

325 It can be observed that, despite having been collected from a small area, the Antarctic 326 PSAs overall are quite heterogeneous. For instance, while the materials collected near the 327 McMurdo Sound and Mt. Erebus are relatively constrained on the Sr-Nd plot (blue circles in 328 Figure 2), the isotopic compositions of the Victoria Land regoliths and drifts are scattered 329 throughout the plot. Measured Sr isotopic ratios range from $0.703041<{ }^{87} \mathrm{Sr} /{ }^{86} \mathrm{Sr}<0.782734$. As

330 for variations in $\varepsilon \mathrm{Nd}$, the range is also quite broad, with $-12.01<\varepsilon \mathrm{Nd}<6.36$. These same $\mathrm{Sr}-\mathrm{Nd}$ 331 data have been incorporated into the regional isotope contour map of fine-grained $(<5 \mu \mathrm{m})$ 332 source materials (Figure 3).

333 The new PSA data from this study are plotted in the three panels of Figure 4, separated 334 by geographic location (MS, SVL, NVL, TV). In this case, MS volcanics remain indicated by 335 blue circles, with orange diamonds representing NVL PSA samples and dark squares for SVL 336 samples, with the exception of TV moraine materials, which are pictured as tan triangles. The 337 first panel (Figure 4a) features the Sr-Nd plot for new bulk fraction samples, the second panel 338 (Figure $4 \mathrm{~b}) \mathrm{Sr}$ and $\mathrm{Nd}$ ratios of complimentary fine fraction $(<5 \mu \mathrm{m})$ material. In the third panel, 339 we have calculated and plotted the isotopic difference between fine and coarse-grained samples. 
Here, it is shown clearly that NVL PSAs are most variable in their Sr and $\mathrm{Nd}$ isotopic compositions. Meanwhile, TV and other SVL samples display little variation in their ${ }^{87} \mathrm{Sr} /{ }^{86} \mathrm{Sr}$ signatures. As for sites outside Victoria Land, Figure 5a takes a closer look at ${ }^{87} \mathrm{Sr} /{ }^{86} \mathrm{Sr}$

343 differences for the MS samples with respect to distance from the Erebus volcano. Particularly for 344 the bulk fraction, it appears that the sites closest to Mt. Erebus (Cape Royds) exhibit the least

345 radiogenic Sr signatures (Figure 5a). Conversely, the data shifts away from more radiogenic $\mathrm{Nd}$ 346 signatures when plotted against increasing distance from the volcano, with the exception of the 347 fine-fraction Knob Point outlier $(\varepsilon \mathrm{Nd}=-0.17)$, located near the bottom left corner of Figure $5 b$. 348 The combined $\mathrm{Hf}$ and $\mathrm{Nd}$ isotopic signatures of fine and bulk samples are plotted in 349 Figure 6. The first panel (Figure 6a) shows that the bulk material plots near the igneous and 350 “zircon-bearing” sediment arrays (as defined by Bayon et al. (2009)). For the bulk fraction, the 351 MS samples plot slightly below the "zircon-bearing" line, while the remaining Victoria Land 352 samples tend towards lower $\varepsilon \mathrm{Hf}$ and $\varepsilon \mathrm{Nd}$ values. A sample of lacustrine sand from the Dry 353 Valleys and the two granitic Frontier Mountains samples sit at the bottom left corner of Figure 6a 354 with the least radiogenic isotopic compositions. In contrast, Figure 6b illustrates more radiogenic 355 Hf signatures for the fine-fraction Victoria Land samples, with the majority plotting between the 356 "seawater" and "zircon-free" sediment arrays (Bayon et al., 2009). The MS samples occupy a 357 similar region in Hf-Nd space for both size fractions.

358 For the purposes of determining provenance based on isotopic composition in a dust 359 "sink," such as an ice core (e.g. Grousset et al., 1992) or sediment core (e.g. Di Vincenzo et al., 360 2010), we list below a summary of our isotopic findings: (1) of all the PSAs considered in this 361 study, materials representing the MS and Ross Island region are by far the most isotopically 362 constrained. While the majority of Victoria Land samples exhibit relatively low, non-radiogenic $363 \mathrm{Nd}$ compositions, $\varepsilon \mathrm{Nd}$ for MS samples are comparatively quite radiogenic (i.e. greater than 364 zero). Both $\mathrm{Hf}$ and $\mathrm{Nd}$ isotopic compositions are highly radiogenic, with approximate ranges of 0 $365<\varepsilon \mathrm{Nd}<6$, and $2<\varepsilon \mathrm{Hf}<7$. Conversely, Sr values obtained for these materials trend towards 366 non-radiogenic $\mathrm{Sr}$, ranging approximately from $0.703<{ }^{87} \mathrm{Sr} /{ }^{86} \mathrm{Sr}<0.709$; (2) for each of the $\mathrm{Sr}$, $367 \mathrm{Nd}$, and Hf isotope systems, the doleritic NVL PSAs occupy a moderate range, with ${ }^{87} \mathrm{Sr} /{ }^{86} \mathrm{Sr}$ 368 falling just outside the MS range (most frequently around ${ }^{87} \mathrm{Sr} /{ }^{86} \mathrm{Sr}=0.711$ ). Based on our 369 limited selection of samples, we would expect radiogenic $\mathrm{Nd}$ and $\mathrm{Hf}$ signatures to range from 370 approximately $-5<\varepsilon \mathrm{Nd}<-1$, and $-2<\varepsilon \mathrm{Hf}<2$, respectively; (3) although some NVL PSA 
371 samples plot closely to SVL values in ${ }^{87} \mathrm{Sr} /{ }^{86} \mathrm{Sr}$ space, regoliths weathered directly from the older 372 granites and gneisses of the Ross Orogeny are particularly radiogenic with respect to $\operatorname{Sr}$ (i.e.

$\left.373{ }^{87} \mathrm{Sr} /{ }^{86} \mathrm{Sr}>0.726\right)$. Our data indicates that granitic and other non-dolerite PSAs occupy a similar

$374 \mathrm{Nd}$ isotopic range to the NVL dolerites; (4) the dataset implies that SVL sands have a fairly 375 defined Sr fingerprint, with $0.712<{ }^{87} \mathrm{Sr} /{ }^{86} \mathrm{Sr}<0.714$. Nd isotopic compositions range from around $-10<\varepsilon N d<-5$ for bulk PSA samples, and slightly more radiogenic (around $-8<\varepsilon \mathrm{Nd}<-$

377 3) for the finer size fraction. As for Hf isotopes, all clay-sized particles fall around $\varepsilon \mathrm{Hf}=0$, while 378 the bulk material falls along, above, and below the zircon-bearing sediment array (Bayon et al., 379 2009), ranging from $-17<\varepsilon \mathrm{Hf}<-6$, and; (5) such as with the other SVL PSAs, moraine material 380 collected from the Taylor Valley occupies a narrow range of Sr isotopes, with $0.710<{ }^{87} \mathrm{Sr} /{ }^{86} \mathrm{Sr}<$ 3810.712 (slightly less radiogenic than the SVL sands). Hf isotopic ratios for bulk TV samples fall in 382 the range of $-12<\varepsilon \mathrm{Hf}<-5$, while $\mathrm{Hf}$ data for fine-fraction materials is limited in this region.

\section{4. Discussion}

\section{$385 \quad 4.1 \mathrm{Sr}$ and Nd isotopes}

386 Due to the variety of lithologies and ages of exposed rocks in Victoria Land and the McMurdo 387 Sound areas, ${ }^{87} \mathrm{Sr} /{ }^{86} \mathrm{Sr}$ and $\varepsilon N d$ vary broadly for the Antarctic PSAs. For the NVL regolith 388 samples, isotopic compositions resemble existing whole rock data for NVL granites, which 389 suggest that ${ }^{87} \mathrm{Sr} /{ }^{86} \mathrm{Sr}$ may vary from 0.705 to 0.730 , with $\varepsilon N d$ between -12.7 and 1.2 (Rocchi et 390 al., 1998, and sources therein). Likewise, the doleritic regolith samples from NVL and SVL fall 391 within the same isotopic ranges as Ferrar dolerite whole rock data presented in Faure et al. 392 (1974) and Hergt et al. (1989). Southern Victoria Land (SVL, Dry Valleys) samples analyzed in 393 this work tend to closely mimic the ${ }^{87} \mathrm{Sr} /{ }^{86} \mathrm{Sr}$ values obtained for PSA samples derived from 394 Beacon sandstone reported in Delmonte et al. (2013). However, our range of $\varepsilon N d$ for SVL 395 materials extends to more radiogenic values than obtained by B. Delmonte and coworkers; that 396 is, while lacustrine and dune sands from this work fall in a similar, confined range $(-8.1<\varepsilon \mathrm{Nd}<$ 397 -7.6) likely due to intense eolian reworking and sorting over time, the new glacial drift materials 398 from SVL and TV are far more diverse, and may be as radiogenic as $\varepsilon N d=2.5$ for the basalt-rich 399 TAYLOR-5 $(<5 \mu \mathrm{m})$, and $\varepsilon N d=0.51$ for sample TAYLOR-1 (also $<5 \mu \mathrm{m}$ ) obtained from an 400 alpine moraine of the Marr Glacier. 
Due to their close proximity to Mt. Erebus and the other volcanic centers of Ross Island,

402 it was expected that MS glacial drifts would be composed at least partially of volcanic materials,

403 yielding the lowest ${ }^{87} \mathrm{Sr} /{ }^{86} \mathrm{Sr}$ signatures and the highest $\varepsilon \mathrm{Nd}$. This prominent volcanic signature is

404 clearly illustrated by green ${ }^{87} \mathrm{Sr} /{ }^{86} \mathrm{Sr}$ contours on the isotope map (Figure 3) near Ross Island and

405 the McMurdo Sound. It is well understood that radiogenic $\mathrm{Sr}$ and $\mathrm{Nd}$ isotopic compositions are

406 distinct for mantle-derived or crust-derived rocks (Faure, 1986); given the distinctive isotopic

407 composition of this PSA, regional dust or ash transport from the McMurdo Sound/Erebus region

408 should be readily identifiable if it is a significant component of the dust flux in local ice cores

409 (Delmonte et al., 2010; Delmonte et al., 2013).

410 As illustrated in Figure 4c, the majority of the MS samples, as well as some of the

411 Victoria Land dusts, are more radiogenic with respect to ${ }^{87} \mathrm{Sr} /{ }^{86} \mathrm{Sr}$ in the finer versus the bulk size

412 fraction, suggesting that the size-dependent fractionation for Sr isotope composition may be

413 important and should continue to be taken into consideration in future PSA and other provenance

414 studies (Kanayama et al., 2005; Meyer et al., 2011). Still, in cases where $\Delta{ }^{87} \mathrm{Sr} /{ }^{86} \mathrm{Sr}$ (Fine -

415 Bulk) is much less than 0 (see again Figure 4c), and/or $\Delta \varepsilon N d$ (Fine - Bulk) veers appreciably

416 from 0 (i.e. the Frontier Mountains granites), we recognize that variations between the bulk and

417 fine samples are completely unrelated to grain-size fractionation. Rather, we suggest that the

418 widespread differences in $\varepsilon \mathrm{Nd}$ between these fine- and bulk-fraction samples can be attributed to

419 variations in/mixing of source rock materials (i.e. a sampling site may serve as both a source and

420 a sink of mineral dust).

421 To further explain, isotopic differences plotted in Figure 4c show that several Victoria

422 Land samples are less radiogenic with respect to $\mathrm{Sr}$ for the fine versus bulk size fraction; in cases

423 where this particular change in ${ }^{87} \mathrm{Sr} /{ }^{86} \mathrm{Sr}$ is combined with an also variable $\varepsilon N d$ signature,

424 especially for fine fraction samples, we propose that the continental dusts and sediments have

425 been mixed with very particles from different lithological terrains (e.g. Delmonte et al., 2013).

426 For example, although coarser grained particles from TV isotopically resemble the other SVL

427 materials, and some of the fine grained TV materials overlap well with SVL fine grained data,

428 there appears to be a volcanic component resulting in higher $\varepsilon N d$ values for two of five of the

429 TV PSAs (the previously mentioned TV-1 and TV-5), wherein isotopic signatures begin to

430 resemble the MS volcanics; Delmonte et al. (2013) cautioned that this background volcanic

431 component complicates the source to sink comparison of fine fraction PSAs to ice core dusts, 
432 and thus, techniques other than $\mathrm{Sr}-\mathrm{Nd}$ isotopic analysis should be used for a clearer 433 discrimination.

434 Moreover, the isotopic similarities between other southern hemisphere PSAs and local 435 dust sources (see Figure 7) prevent us from determining whether or not southern South America

436 (or other remote sources) remain significant contributors of dust to the EAIS during the

437 Holocene (Delmonte et al., 2010) (Figure 7), which is why we chose to further characterize the 438 PSA samples using the Hf isotope system. Aarons et al. (2013) found that the quantity of non439 radiogenic Hf present in an atmospheric dust sample can be correlated to the distance traveled 440 from source area, and thus may be used to differentiate near and far sources of eolian material.

\section{$442 \quad 4.2$ Hf isotopes}

443 On the basis of Vervoort et al.'s “terrestrial array" (1999), we would anticipate negative $\varepsilon H f$ and $444 \varepsilon N d$ values to correspond with primary rocks or bulk sediments derived from old continental 445 crust, such as the Antarctic granites and sandstones. Figure 6 illustrates that indeed all bulk 446 fraction Victoria Land samples have $\varepsilon \mathrm{Hf}<-5$, discounting the five NVL samples composed of or 447 containing dolerite fragments (see gray boxes in Figure 6). Meanwhile, only two PSA samples 448 (FM-1 and VH-3, both from NVL) display $\varepsilon \mathrm{Hf}<-5$ in their fine fraction; from Figure 6a to 449 Figure 6b, NVL, SVL, and TV samples have shifted away from the zircon-poor area of the plot 450 (lower left), and towards the radiogenic MS samples in the clay-rich upper-right quadrant. The 451 observed differences between the two size fractions considered in this study may indicate that 452 dense zircon particles have fallen out of the air column during wind transport (Aarons et al., 453 2013). Indeed, differences between the fine and bulk fractions for PSA materials collected from 454 the same sampling locale in terms of their radiogenic Hf isotope compositions may be diagnostic 455 of inconsistent source rocks; that is, while the coarse fraction may have been weathered from the 456 underlying bedrock, the finer fraction may have originated from a more distant source, (i.e. 457 sample was already subjected to eolian transport and deposited at the PSA sample site).

458 In Figure 6, we note that the NVL dolerites do not show a significant shift in Hf isotope 459 composition between the two size fractions (especially in comparison to the granitic materials, 460 also labeled on the plot, although we are limited by a small sample size); based on homogeneous 461 signatures for the dolerite samples, we recommend that the fine and coarse grain size fractions of 462 dolerite materials are truly representative of the same PSA composition, having been derived 
463 from the same parent rock source. Yet, we note that zircon (and therefore Hf) is likely present in 464 smaller quantities for these dolerites than with the other rock types (i.e. sandstone, granite), in 465 which case $\varepsilon \mathrm{Hf}$ may not be the most ideal isotopic tracer for this particular lithology. For the MS 466 samples on the other hand, we did not observe major differences in Hf isotopic compositions 467 between the size fractions, in this case due to the materials being more highly weathered and 468 well-sorted, and of course, volcanic in nature. Finally, although we have noted that the Sr-Nd 469 isotopic ranges of SVL and TV materials tend to resemble other southern hemisphere dust 470 sources, should particles archived in a natural "sink" such as a local, coastal ice core fall within 471 Hf isotopic ranges reported in this study (most importantly, with non-radiogenic Hf), we believe 472 that the material is most likely sourced locally from Victoria Land and not from a remote source. 473 In summary, $\mathrm{Nd}-\mathrm{Hf}$ isotopes may be used to study the proximity of dust or sediments to 474 the original source (see Aarons et al., 2013 for a more extensive discussion), and can potentially 475 be a useful proxy to track changes in wind velocity and/or direction in relation to proximal and 476 distal depositional sites (Garçon et al., 2013). Coarse (particle diameter $>5 \mu \mathrm{m}$ ) PSA materials 477 generated from zircon-rich sandstones and granites are likely to be highly non-radiogenic in Hf, 478 whereas fine-grained particles more susceptible to long-range versus short-range transport will 479 have a more radiogenic signature with respect to Hf due to absence of the mineral zircon.

480 Measurements of Hf isotopes from new or pre-existing PSA sites should provide further 481 constraints on the application of this proxy; currently, our ability to use Hf isotopic ratios to 482 identify dust provenances is limited by the lack of geochemical data in dust collected from 483 potential source regions. The new Antarctic PSA data presented here greatly enriches the limited 484 global catalogue of Nd-Hf isotopic signatures.

\section{Conclusions}

487 For geochemical studies of dust provenance, interpreting the information provided by radiogenic 488 isotopes requires first a keen understanding of isotopic fractionation due to physical and 489 chemical weathering, and internal sorting processes during transport. While the Sr-Nd isotopic 490 compositions of sediments from Victoria Land and the McMurdo Sound sector described in this 491 work - as well as those presented in previously published studies - generally correspond as 492 expected to source rock lithologies, the potential background presence of aerosols transported 493 from long-range southern hemisphere sources or from regional volcanic activity in some cases 
494 complicates the direct source-to-sink comparison of isotopic signatures. In particular, the $\mathrm{Sr}-\mathrm{Nd}$ 495 isotopic fingerprints for fine-grained SVL and TV materials alone may be indistinguishable from 496 those of several other (remote) southern hemisphere sources, such as South America and New 497 Zealand. For these sites, incorporating Hf isotope analysis may lead to more accurate source 498 identification, although additional sampling campaigns in both Antarctica and other southern 499 hemisphere continents will be required in order to achieve a more precise $\mathrm{Nd}-\mathrm{Hf}$ characterization 500 of potentially important dust sources. Furthermore, because many PSA samples analyzed in this 501 work are more radiogenic with respect to ${ }^{87} \mathrm{Sr} /{ }^{86} \mathrm{Sr}$ in the finer versus the bulk size fraction, we 502 suggest that the grain size effect for radiogenic Sr isotopes should continue to be taken into 503 consideration in future dust and sediment provenance studies. On the other hand, some samples

504 from our study (especially the NVL granites) are quite different in terms of ${ }^{87} \mathrm{Sr} /{ }^{86} \mathrm{Sr}, \varepsilon \mathrm{Nd}$, or 505 both in their different size fractions in a way that does not suggest isotopic fractionation was at 506 play; rather, it is highly possible that some selected PSA sites are both sources and sinks of 507 mineral material, and may not be ideal sampling locales for future studies hoping to identify 508 primary sources of mineral material. Moving forward, we advocate that the expansion of an 509 isotopic catalogue for Antarctic PSAs should include multiple size fractions, as obtaining 510 signatures for coarser-grained particles more susceptible to short-range transport may better 511 allow us to rule out global sources of dust when examining local sinks such as sediment cores 512 and ice cores.

\section{Acknowledgements}

515 This work was funded by NSF OPP Antarctic Glaciology Award 1236702 to S. M. Aciego, the 516 Rackham Graduate School at the University of Michigan, and the Turner Award from the 517 Department of Earth and Environmental Sciences at the University of Michigan. Logistic support 518 to C. Baroni, B. Delmonte, and M. C. Salvatore was provided by the Italian National Antarctic 519 Programme (PNRA). The authors thank Brenda Hall and Paul Augustinus for their help with 520 sample collection, Lang Farmer and one anonymous reviewer for providing constructive 521 feedback on the manuscript, and Sarah Aarons, Bryan Sell, Emily Stevenson, and Sean Scott for 522 various analytical assistance. 
526 Figure 1. Location map indicating PSA sampling regions and individual sites, with the East

527 Antarctic Ice Sheet (EAIS) shaded in white, the Ross Sea in blue, and exposed rock surfaces in 528 brown. Note: orientation of north arrow. Inset provides context for Antarctic ice core drilling 529 sites Dome C, Vostok, Taylor Dome, and TALDICE.

530

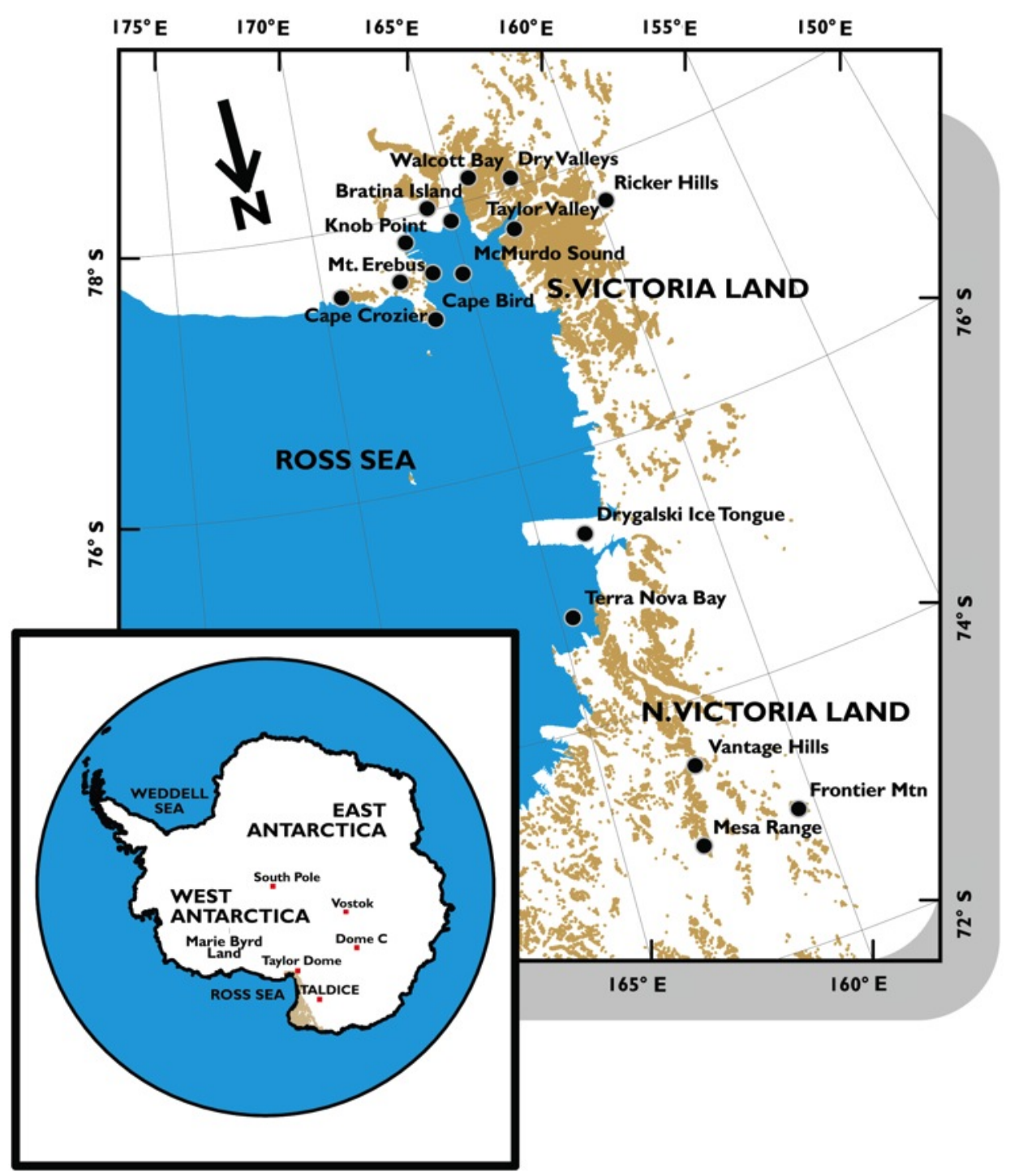


536 Figure 2. Sr-Nd plot of PSA dust from Antarctica's Victoria Land and McMurdo Sound regions.

537 In color, PSA data measured in this study, including volcanic Knob Point end-member (MS), and 538 granitic Frontier Mountains end-member (NVL); gray symbols (as labeled), previously measured 539 PSAs from Holocene raised beaches, eolian silt and sand traps, glacial drifts, and regoliths from 540 Delmonte et al. (2010); also in color, volcanic samples from Sims et al. (2008).

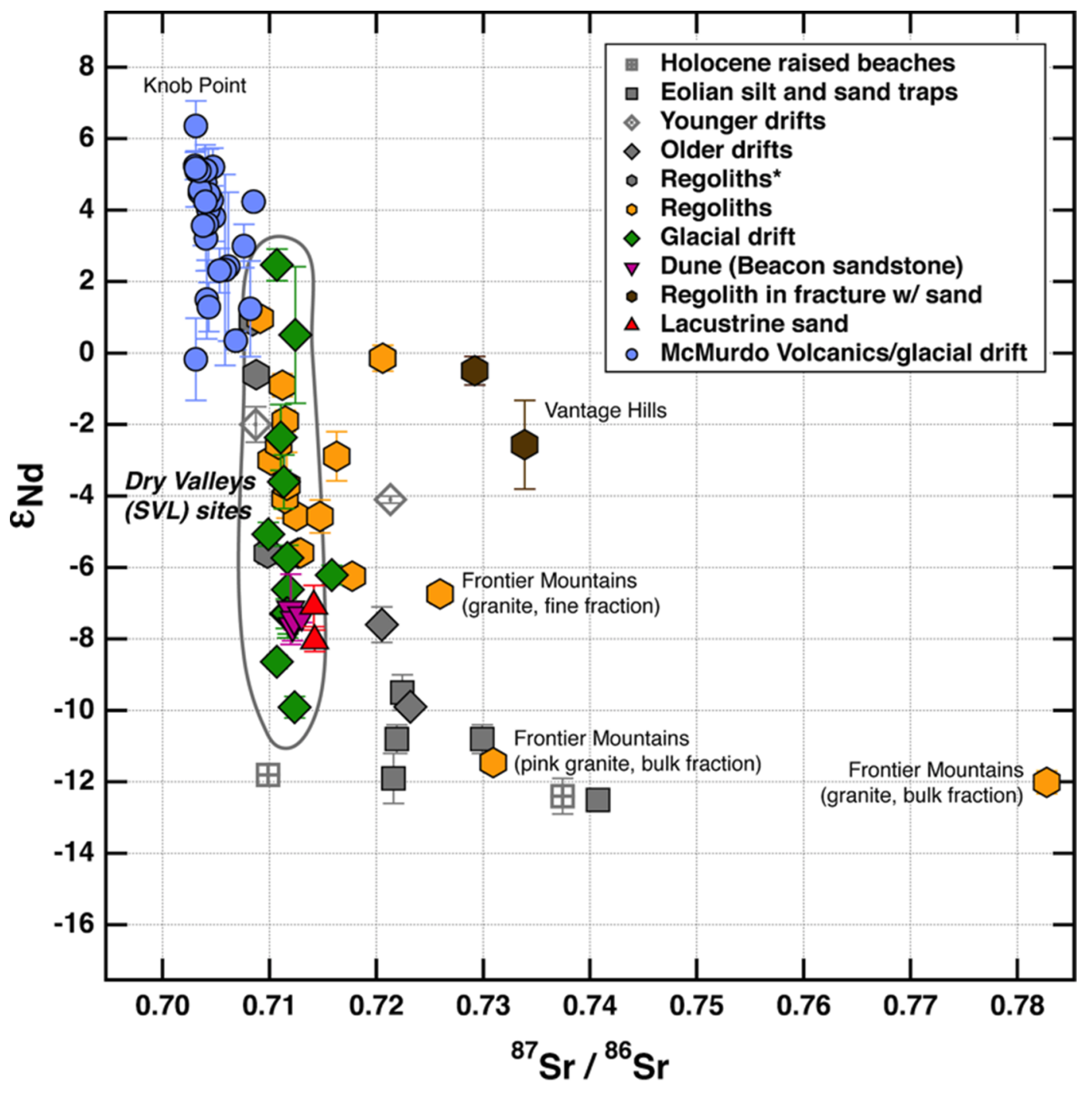


547 Figure 3. Isotope contour map of fine-fraction $(<5 \mu \mathrm{m}$ diameter) PSA samples in Antarctica's

548 McMurdo Sound and Victoria Land regions, paired with previously published PSAs from

549 Delmonte et al. (2010). Nd and Sr contours were determined by inverse distance weighted

550 interpolation using ArcGis, with variations in $\mathrm{Sr}$ isotopic ratios defined by color, and $\mathrm{Nd}$ ratios

551 separated by black contour lines. The MS and Ross Ice Shelf areas (southern samples; note

552 orientation of north arrow) appear to be most radiogenic in terms of $\mathrm{Nd}$, and least radiogenic for

$553 \mathrm{Sr}$, whereas the high-elevation nunataks of NVL exhibit the most radiogenic Sr compositions.

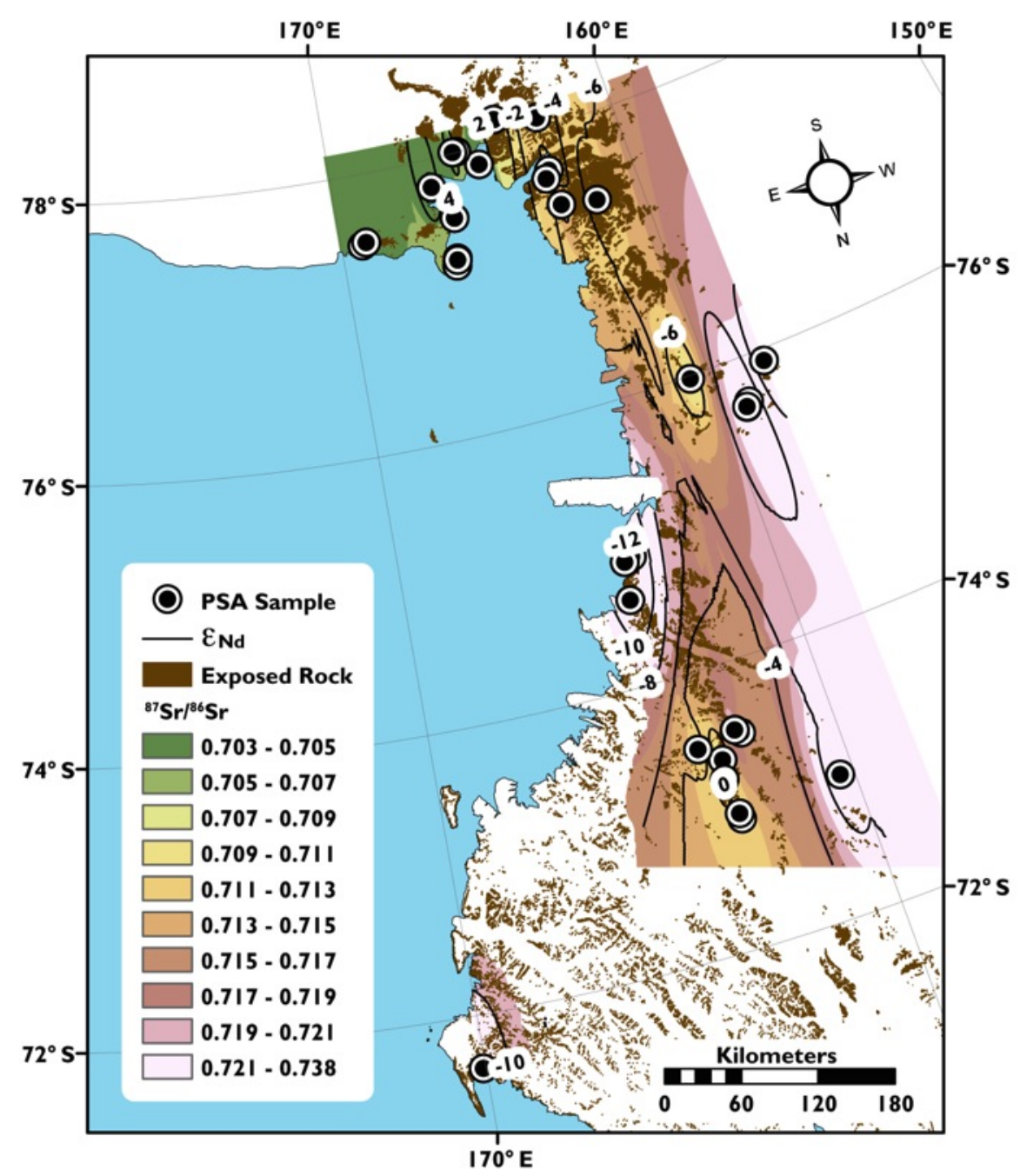


557 Figure 4. (a) Sr-Nd isotopic compositions of bulk fraction material measured in this study.

558 Light-blue circles, glacial drift strongly influenced by McMurdo Volcanics; orange diamonds,

559 Northern Victoria Land; dark-blue squares, Dry Valleys sand; and tan triangles, Taylor Valley

560 moraine material; (b) Sr and $\mathrm{Nd}$ isotopic ratios of complimentary fine fraction $(<5 \mu \mathrm{m}$, more

561 highly weathered) material; (c) difference between fine- and course-grained samples (i.e. bulk

562 ratio subtracted from fine ratio), with ${ }^{87} \mathrm{Sr} /{ }^{86} \mathrm{Sr}$ differences multiplied by 1000 to better detect

563 trends visually.
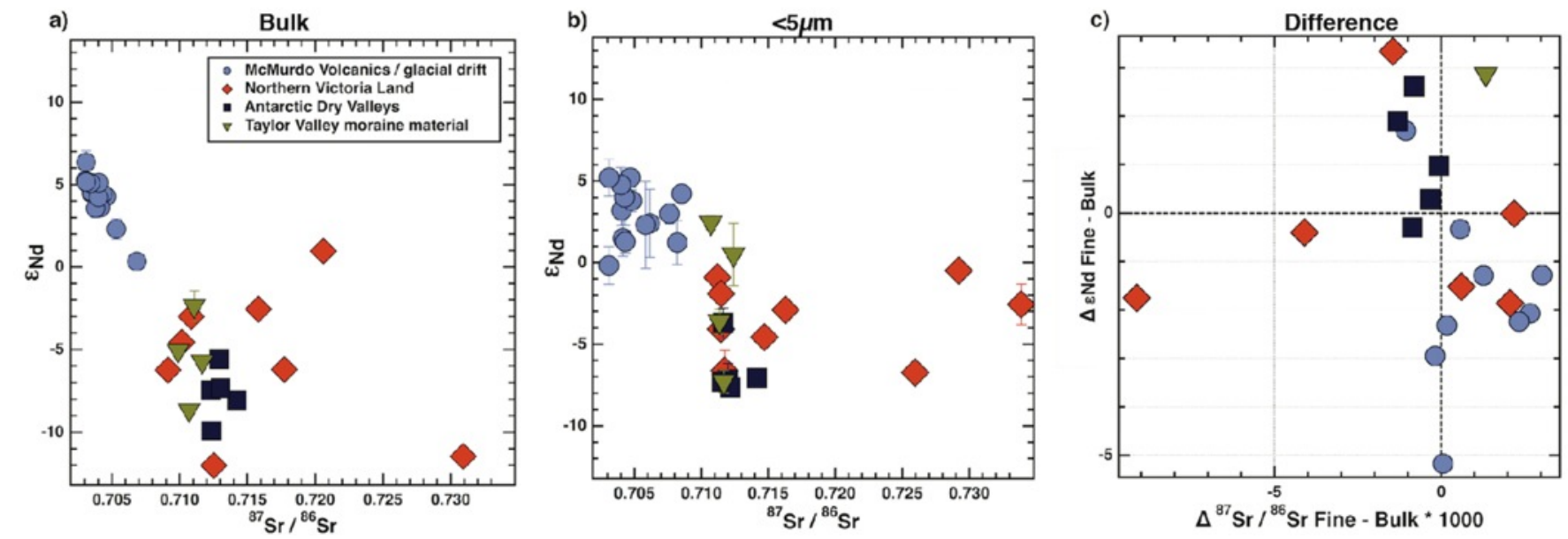

564

565 Figure 5. (a) Strontium isotopic compositions of volcanic/glacial drift material with respect to

566 distance from the Mt. Erebus volcano. Red circles, fine fraction $(<5 \mu \mathrm{m})$ dust; and black

567 hexagons, bulk fraction samples; (b) $\varepsilon N d$ isotopic compositions of the same PSA materials, also

568 with respect to distance from Mt. Erebus.
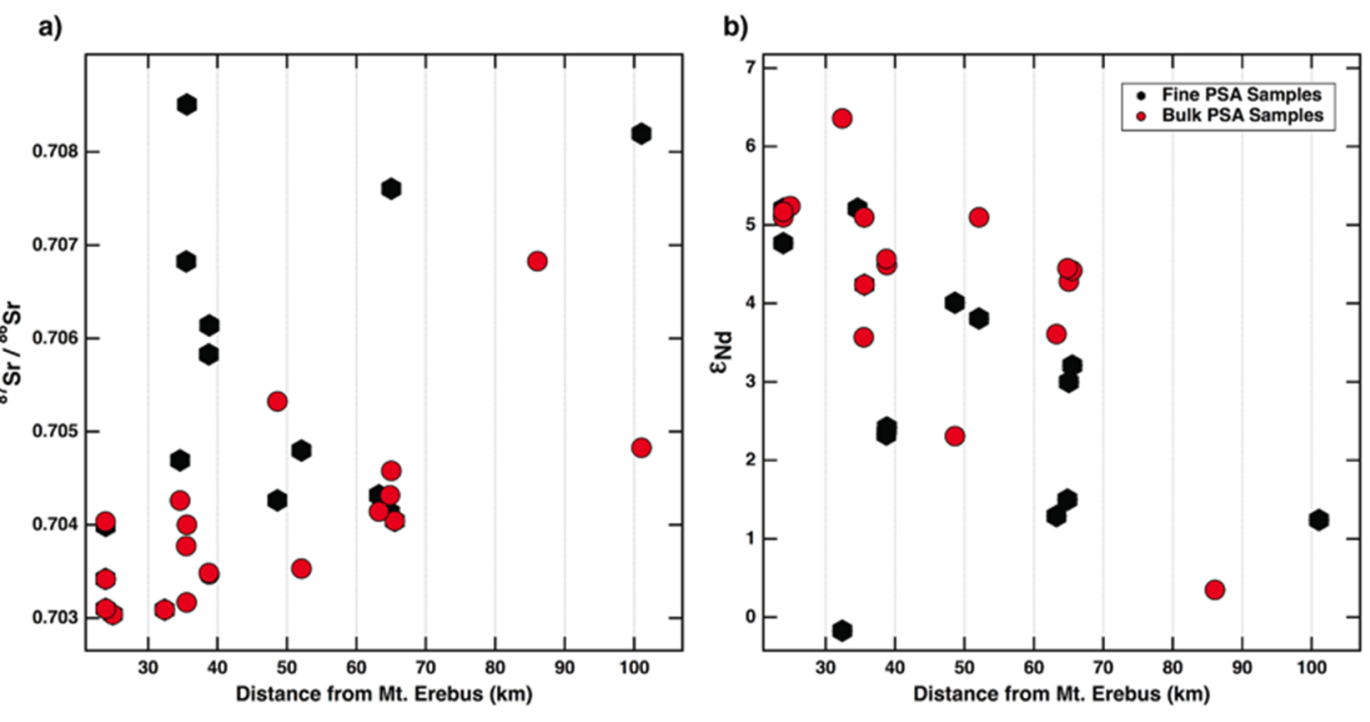

569 
570 Figure 6. (a) Nd-Hf isotopic signatures of bulk PSA material from this study, plotted along the 571 steep, zircon-bearing sediment $(\varepsilon \mathrm{Hf}=1.80 \varepsilon \mathrm{Nd}+2.35)$ and igneous arrays $(\varepsilon \mathrm{Hf}$

$572=1.37 \varepsilon \mathrm{Nd}+2.89)$ as defined by Bayon et al. (2009). The dashed line represents our calculated

573 linear trend for the bulk fraction Victoria Land samples (NVL, SVL, and TV) $(\varepsilon H f=0.99 \varepsilon N d-$ $\left.5741.07 ; \mathrm{r}^{2}=0.54827\right)$. Doleritic samples are surrounded by gray boxes, with samples BULK-MR1 575 and BULK-SM1 labeled for comparison to the corresponding fine fraction data. For this same 576 purpose, granitic samples BULK-FM1, BULK-MW1, and BULK-DV2 are also labeled; (b) fine 577 fraction dust plotted in Nd-Hf space, accompanied by the seawater $(\varepsilon \mathrm{Hf}=0.39 \varepsilon \mathrm{Nd}+6.2)$, 578 zircon-free $(\varepsilon \mathrm{Hf}=0.91 \varepsilon \mathrm{Nd}+3.1)$, igneous, and zircon-bearing sediment arrays (2009). Again, 579 dolerites are surrounded by gray boxes, although a smaller sample size and/or concentration for 580 these materials resulted in markedly less reportable data than for the more abundant bulk 581 materials, and therefore only two data points (MR1 and SM1) are reported. Fine fraction granitic 582 samples FM1, MW1, and DV2 are also labeled.

583

584
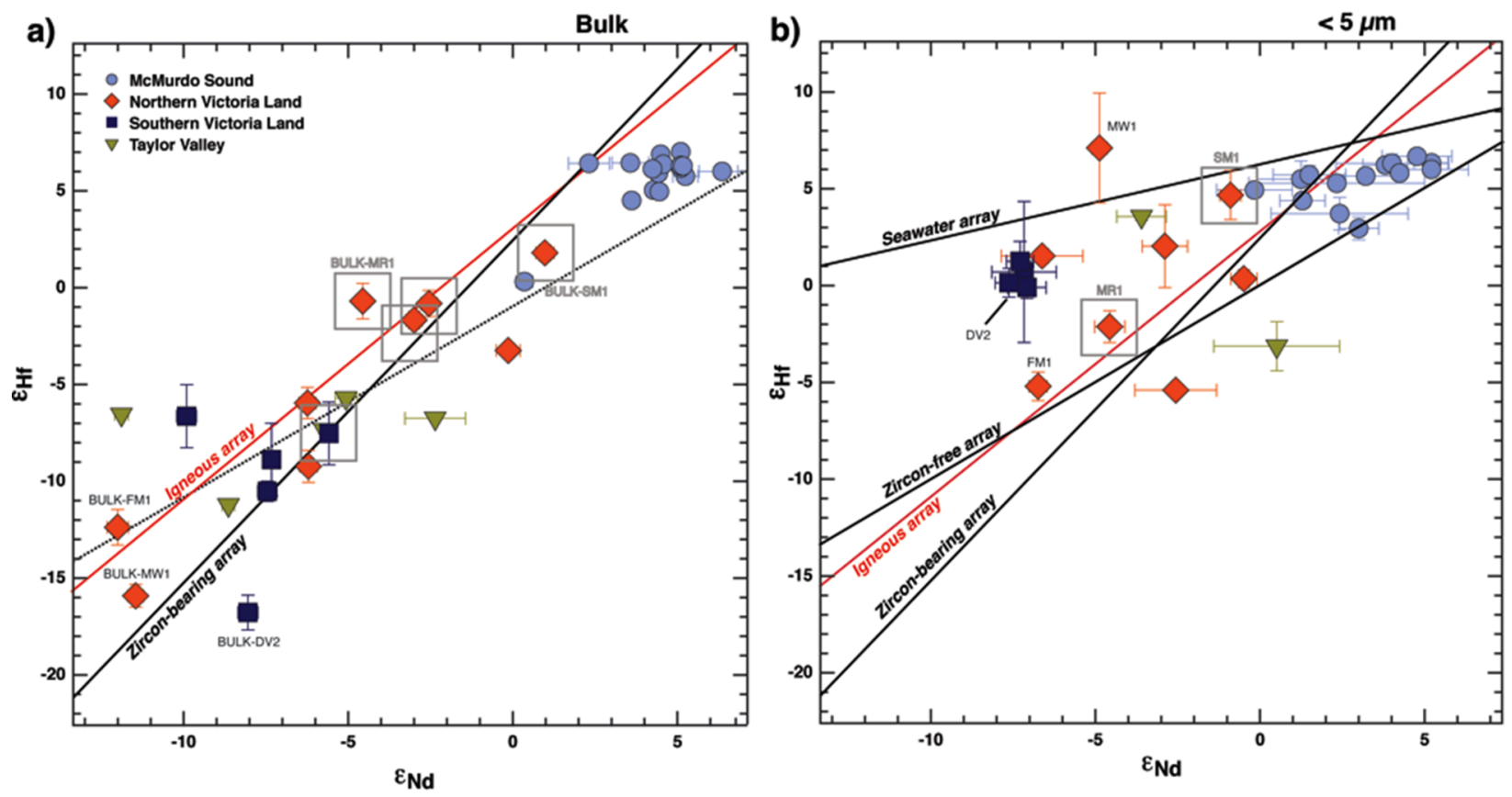

585 
589 Figure 7. Sr-Nd isotopic signatures of Antarctic PSA dust from this study and previous works, 590 plotted alongside dust from remote southern hemisphere sources.

591

Erebus (Sims et al., 2008)

Southern Victoria Land, Dry Valleys (Delmonte et al., 2010)

Northern Victoria Land (Delmonte et al., 2010)

New Zealand (Delmonte et al., 2004)

South America (Delmonte et al, 2004; Grousset et al., 1992)

South Africa (Delmonte et al., 2004; Grousset et al., 1992)

Australia (Delmonte et al., 2004; Revel-Rolland et al., 2006)

Northern Victoria Land

McMurdo Sound/Erebus

Southern Victoria Land, Dry Valleys

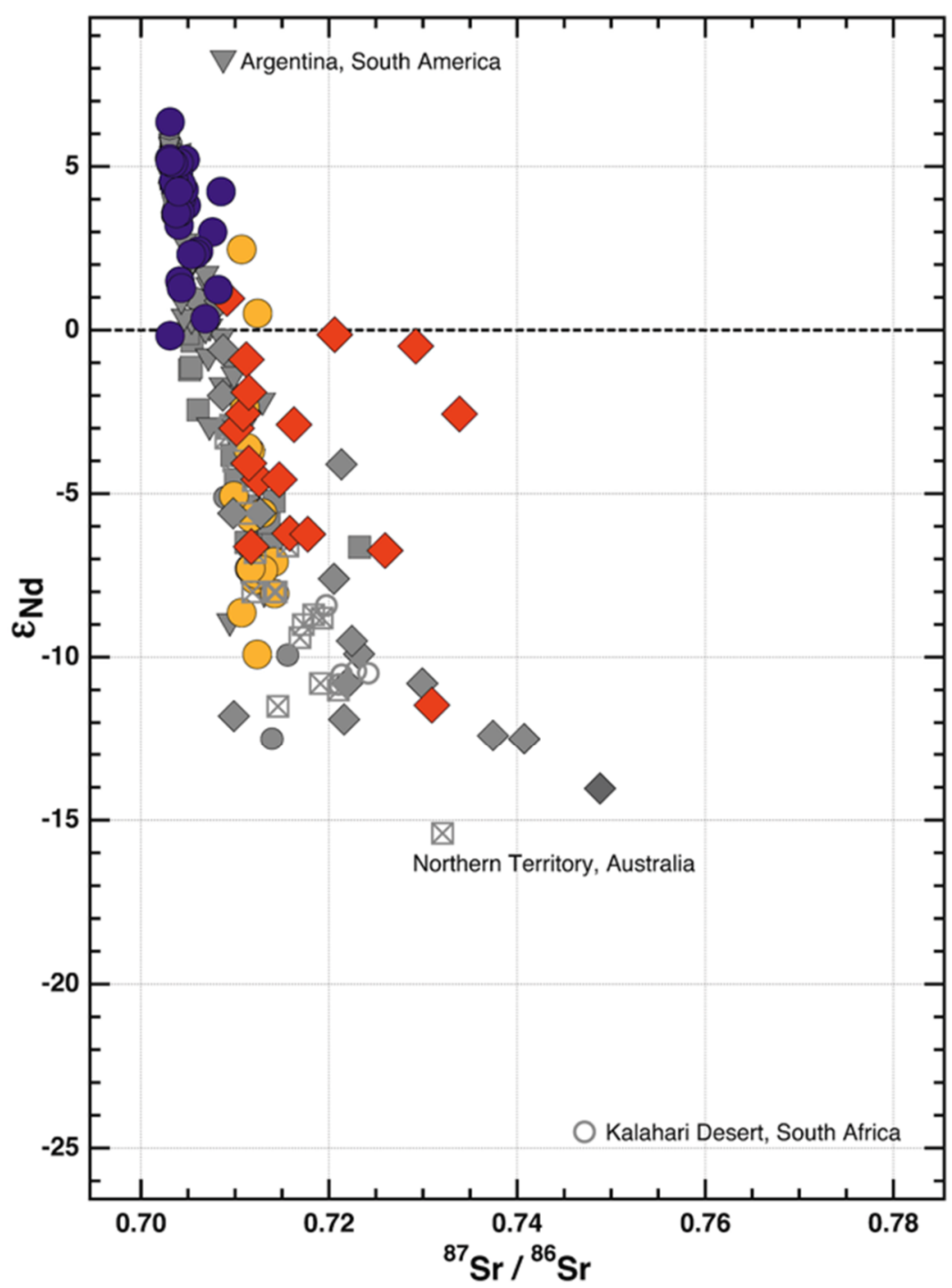




\section{References}

594 Aarons, S.M., Aciego, S., Gleason, J., 2013. Variable Hf Sr Nd radiogenic isotopic compositions in a Saharan dust storm over the Atlantic: Implications for dust flux to oceans, ice sheets and the terrestrial biosphere. Chemical Geology 349, 18-26.

Aciego, S.M., Bourdon, B., Lupker, M., Rickli, J., 2009. A new procedure for separating and measuring radiogenic isotopes (U, Th, $\mathrm{Pa}, \mathrm{Ra}, \mathrm{Sr}, \mathrm{Nd}, \mathrm{Hf}$ ) in ice cores. Chemical Geology 266, 194-204.

600 Arendt, C.A., Aciego, S.M., Sims, K.W., Robbins, M., 2014. Sequential Separation of Uranium, 601 Hafnium and Neodymium from Natural Waters Concentrated by Iron Coprecipitation.

602 Geostandards and Geoanalytical Research.

603 Armienti, P., Baroni, C., 1999. Cenozoic climatic change in Antarctica recorded by volcanic 604 activity and landscape evolution. Geology 27, 617-620.

605 Baroni, C., Biasini, A., Bondesan, A., Denton, G., Frezzotti, M., Grigioni, P., Meneghel, M., 606 Orombelli, G., Salvatore, M., Della Vedova, A., 2005a. Mount Melbourne Quadrangle, Victoria 607 Land, Antarctica 1: 250,000 (Antarctic Geomorphological and Glaciological Map Series).

608 Fluctuations of Glaciers. A contribution to the Global Environment Monitoring Service (GEMS) 609 and the International Hydrological Programme, ed. W. Haeberli, M. Zemp, M. Hoelzle, R.

610 Frauenfelder 8, 38-40.

611 Baroni, C., Fasano, F., Giorgetti, G., Salvatore, M.C., Ribecai, C., 2008. The Ricker Hills tillite 612 provides evidence of Oligocene warm-based glaciation in Victoria Land, Antarctica. Global and 613 Planetary Change 60, 457-470.

614 Baroni, C., Frezzotti, M., Salvatore, M.C., Meneghel, M., Tabacco, I.E., Vittuari, L., Bondesan, 615 A., Biasini, A., Cimbelli, A., Orombelli, G., 2004. Antarctic geomorphological and glaciological 616 1: 250000 map series: Mount Murchison quadrangle, northern Victoria Land. Explanatory notes. 617 Annals of Glaciology 39, 256-264.

618 Baroni, C., Noti, V., Ciccacci, S., Righini, G., Salvatore, M.C., 2005b. Fluvial origin of the 619 valley system in northern Victoria Land (Antarctica) from quantitative geomorphic analysis. 620 Geological Society of America Bulletin 117, 212-228.

621 Baroni, C., Orombelli, G., 1991. Holocene raised beaches at Terra Nova Bay, Victoria Land, 622 Antarctica. Quaternary Research 36, 157-177.

623 Basile, I., Grousset, F.E., Revel, M., Petit, J.R., Biscaye, P.E., Barkov, N.I., 1997. Patagonian 624 origin of glacial dust deposited in East Antarctica (Vostok and Dome C) during glacial stages 2, 6254 and 6. Earth and Planetary Science Letters 146, 573-589.

626 Bayon, G., Burton, K.W., Soulet, G., Vigier, N., Dennielou, B., Etoubleau, J., Ponzevera, E., 627 German, C.R., Nesbitt, R.W., 2009. Hf and Nd isotopes in marine sediments: Constraints on 628 global silicate weathering. Earth and Planetary Science Letters 277, 318-326. 
Bayon, G., Vigier, N., Burton, K.W., Brenot, A., Carignan, J., Etoubleau, J., Chu, N.-C., 2006. 630 The control of weathering processes on riverine and seawater hafnium isotope ratios. Geology $63134,433-436$.

632 Biscaye, P.E., Grousset, F.E., Revel, M., Van der Gaast, S., Zielinski, G.A., Vaars, A., Kukla, 633 G., 1997. Asian provenance of glacial dust (stage 2) in the Greenland Ice Sheet Project 2 Ice 634 Core, Summit, Greenland. Journal of Geophysical Research: Oceans 102, 26765-26781.

635 Blichert-Toft, J., Arndt, N.T., Gruau, G., 2004. Hf isotopic measurements on Barberton 636 komatiites: effects of incomplete sample dissolution and importance for primary and secondary 637

Bory, A., Wolff, E., Mulvaney, R., Jagoutz, E., Wegner, A., Ruth, U., Elderfield, H., 2010. Multiple sources supply eolian mineral dust to the Atlantic sector of coastal Antarctica: Evidence from recent snow layers at the top of Berkner Island ice sheet. Earth and Planetary Science Letters 291, 138-148.

Bory, A.J.M., Biscaye, P.E., Svensson, A., Grousset, F.E., 2002. Seasonal variability in the origin of recent atmospheric mineral dust at NorthGRIP, Greenland. Earth and Planetary Science Letters 196, 123-134.

Bory, A.M., Biscaye, P.E., Piotrowski, A., Steffensen, J.P., 2003. Regional variability of ice core dust composition and provenance in Greenland. Geochemistry, Geophysics, Geosystems 4.

Bristow, C.S., Augustinus, P.C., Wallis, I., Jol, H., Rhodes, E., 2010a. Investigation of the age and migration of reversing dunes in Antarctica using GPR and OSL, with implications for GPR on Mars. Earth and Planetary Science Letters 289, 30-42.

Bristow, C.S., Jol, H., Augustinus, P., Wallis, I., 2010b. Slipfaceless 'whaleback'dunes in a polar desert, Victoria Valley, Antarctica: insights from ground penetrating radar. Geomorphology 114, 361-372.

Capponi, G., Meccheri, M., Pertusati, P., 1997. Mount Murchison quadrangle (Victoria Land), GIGAMAP. Scale.

Carmignani, L., Ghezzo, C., Gosso, G., Lombardo, B., Meccheri, M., Montrasio, A., Pertusati, P.C., and Salvini, F., 1989. Geological map of the area between David and Mariner Glaciers, Victoria Land Antarctica, Memorie Società Geologica Italiana.

Carpentier, M., Chauvel, C., Maury, R.C., Mattielli, N., 2009. The "zircon effect" as recorded by the chemical and Hf isotopic compositions of Lesser Antilles forearc sediments. Earth and Planetary Science Letters 287, 86-99.

Charlier, B., Ginibre, C., Morgan, D., Nowell, G., Pearson, D., Davidson, J., Ottley, C., 2006. Methods for the microsampling and high-precision analysis of strontium and rubidium isotopes at single crystal scale for petrological and geochronological applications. Chemical Geology 232, 114-133. 
Chen, J., Li, G., Yang, J., Rao, W., Lu, H., Balsam, W., Sun, Y., Ji, J., 2007. Nd and Sr isotopic characteristics of Chinese deserts: Implications for the provenances of Asian dust. Geochimica et Cosmochimica Acta 71, 3904-3914.

Dasch, E.J., 1969. Strontium isotopes in weathering profiles, deep-sea sediments, and sedimentary rocks. Geochimica et Cosmochimica Acta 33, 1521-1552.

Delmonte, B., Andersson, P., Hansson, M., Schöberg, H., Petit, J.-R., Basile - Doelsch, I., Maggi, V., 2008. Aeolian dust in East Antarctica (EPICA - Dome C and Vostok): Provenance during glacial ages over the last 800 kyr. Geophysical Research Letters 35.

Delmonte, B., Andersson, P., Schöberg, H., Hansson, M., Petit, J., Delmas, R., Gaiero, D., Maggi, V., Frezzotti, M., 2010. Geographic provenance of aeolian dust in East Antarctica during Pleistocene glaciations: preliminary results from Talos Dome and comparison with East Antarctic and new Andean ice core data. Quaternary Science Reviews 29, 256-264.

Delmonte, B., Baroni, C., Andersson, P.S., Narcisi, B., Salvatore, M.C., Petit, J.R., Scarchilli, C., Frezzotti, M., Albani, S., Maggi, V., 2013. Modern and Holocene aeolian dust variability from Talos Dome (Northern Victoria Land) to the interior of the Antarctic ice sheet. Quaternary Science Reviews 64, 76-89.

Delmonte, B., Basile-Doelsch, I., Petit, J.-R., Maggi, V., Revel-Rolland, M., Michard, A., Jagoutz, E., Grousset, F., 2004a. Comparing the Epica and Vostok dust records during the last 220,000 years: stratigraphical correlation and provenance in glacial periods. Earth-Science Reviews 66, 63-87.

Delmonte, B., Petit, J.R., Andersen, K.K., Basile-Doelsch, I., Maggi, V., Ya Lipenkov, V., 2004b. Dust size evidence for opposite regional atmospheric circulation changes over east Antarctica during the last climatic transition. Clim Dyn 23, 427-438.

Delmonte, B., Petit, J.R., Basile-Doelsch, I., Jagoutz, E., Maggi, V., 2007. 6. Late quaternary interglacials in East Antarctica from ice-core dust records. Developments in Quaternary Sciences 7, 53-73.

Denton, G.H., Sugden, D.E., Marchant, D.R., Hall, B.L., Wilch, T.I., 1993. East Antarctic Ice Sheet sensitivity to Pliocene climatic change from a Dry Valleys perspective. Geografiska Annaler. Series A. Physical Geography, 155-204.

Di Nicola, L., Baroni, C., Strasky, S., Salvatore, M.C., Schlüchter, C., Akçar, N., Kubik, P.W., Wieler, R., 2012. Multiple cosmogenic nuclides document the stability of the East Antarctic Ice Sheet in northern Victoria Land since the Late Miocene (5-7 Ma). Quaternary Science Reviews 57, 85-94.

Di Nicola, L., Strasky, S., Schlüchter, C., Salvatore, M.C., Akçar, N., Kubik, P.W., Christl, M., Kasper, H.U., Wieler, R., Baroni, C., 2009. Multiple cosmogenic nuclides document complex Pleistocene exposure history of glacial drifts in Terra Nova Bay (northern Victoria Land, Antarctica). Quaternary Research 71, 83-92. 
Di Vincenzo, G., Bracciali, L., Del Carlo, P., Panter, K., Rocchi, S., 2010. 40Ar-39Ar dating of volcanogenic products from the AND-2A core (ANDRILL Southern McMurdo Sound Project, Antarctica): correlations with the Erebus Volcanic Province and implications for the age model of the core. Bulletin of Volcanology 72, 487-505.

Esser, R.P., Kyle, P.R., McIntosh, W.C., 2004. 40Ar/39Ar dating of the eruptive history of Mount Erebus, Antarctica: volcano evolution. Bulletin of Volcanology 66, 671-686.

Faure, G., Jones, L.M., Owen, L., 1974. Isotopic composition of strontium and geologic history of the basement rocks of Wright Valley, southern Victoria Land, Antarctica. New Zealand journal of geology and geophysics 17, 611-627.

Feng, J.-L., Hu, Z.-G., Ju, J.-T., Zhu, L.-P., 2011. Variations in trace element (including rare earth element) concentrations with grain sizes in loess and their implications for tracing the provenance of eolian deposits. Quaternary International 236, 116-126.

Fountain, A.G., Lyons, W.B., Burkins, M.B., Dana, G.L., Doran, P.T., Lewis, K.J., McKnight, D.M., Moorhead, D.L., Parsons, A.N., Priscu, J.C., 1999. Physical controls on the Taylor Valley ecosystem, Antarctica. Bioscience 49, 961-971.

Gabrielli, P., Wegner, A., Petit, J.R., Delmonte, B., De Deckker, P., Gaspari, V., Fischer, H., Ruth, U., Kriews, M., Boutron, C., 2010. A major glacial-interglacial change in aeolian dust composition inferred from Rare Earth Elements in Antarctic ice. Quaternary Science Reviews $29,265-273$.

Gaiero, D.M., 2007. Dust provenance in Antarctic ice during glacial periods: From where in southern South America? Geophysical Research Letters 34.

Garçon, M., Chauvel, C., France-Lanord, C., Huyghe, P., Lavé, J., 2013. Continental sedimentary processes decouple $\mathrm{Nd}$ and $\mathrm{Hf}$ isotopes. Geochimica et Cosmochimica Acta 121, 177-195.

Grousset, F.E., Biscaye, P.E., 2005. Tracing dust sources and transport patterns using Sr, Nd and $\mathrm{Pb}$ isotopes. Chemical Geology 222, 149-167.

Grousset, F.E., Biscaye, P.E., Revel, M., Petit, J.-R., Pye, K., Joussaume, S., Jouzel, J., 1992. Antarctic (Dome C) ice-core dust at 18 k.y. B.P.: Isotopic constraints on origins. Earth and Planetary Science Letters 111, 175-182.

Gunn, B.M., Warren, G., 1962. Geology of Victoria Land between the Mawson and Mulock Glaciers, Antarctica. Trans-antarctic expedition Committee.

Hall, B.L., Denton, G.H., 2000a. Extent and chronology of the Ross Sea ice sheet and the Wilson Piedmont Glacier along the Scott Coast at and since the last glacial maximum. Geografiska Annaler: Series A, Physical Geography 82, 337-363. 
Hall, B.L., Denton, G.H., 2000b. Radiocarbon chronology of Ross Sea drift, eastern Taylor Valley, Antarctica: Evidence for a grounded ice sheet in the Ross Sea at the last glacial maximum. Geografiska Annaler. Series A. Physical Geography, 305-336.

Hall, B.L., Denton, G.H., Lux, D.R., Bockheim, J.G., 1993. Late Tertiary Antarctic paleoclimate and ice-sheet dynamics inferred from surficial deposits in Wright Valley. Geografiska Annaler. Series A. Physical Geography, 239-267.

Hergt, J.M., Chappell, B.W., Faure, G., Mensing, T.M., 1989. The geochemistry of Jurassic dolerites from Portal Peak, Antarctica. Contr. Mineral. and Petrol. 102, 298-305.

Jacobsen, S.B., Wasserburg, G., 1980. Sm-Nd isotopic evolution of chondrites. Earth and Planetary Science Letters 50, 139-155.

Jweda, J., Bolge, L., Class, C., Goldstein, S.L., 2015. High Precision Sr - Nd - Hf - Pb Isotopic Compositions of USGS Reference Material BCR - 2. Geostandards and Geoanalytical Research.

Kanayama, S., Yabuki, S., Zeng, F., Liu, M., Shen, Z., Liu, L., Yanagisawa, F., Abe, O., 2005. Size-Dependent Geochemical Characteristics of Asian Dust \&mdash;Sr and Nd Isotope Compositions as Tracers for Source Identification\&mdash. Journal of the Meteorological Society of Japan. Ser. II 83A, 107-120.

Kelly, M.A., Denton, G.H., Hall, B.L., 2002. Late Cenozoic paleoenvironment in southern

754 Geological Society of America Bulletin 114, 605-618.

Kyle, P.R., Meeker, K., Finnegan, D., 1990. Emission rates of sulfur dioxide, trace gases and metals from Mount Erebus, Antarctica. Geophysical Research Letters 17, 2125-2128.

Lanci, L., Delmonte, B., Maggi, V., Petit, J.-R., Kent, D.V., 2008. Ice magnetization in the EPICA - Dome C ice core: Implication for dust sources during glacial and interglacial periods. Journal of Geophysical Research: Atmospheres (1984-2012) 113.

\section{3}

Lapen, T.J., Mahlen, N.J., Johnson, C.M., Beard, B.L., 2004. High precision Lu and Hf isotope analyses of both spiked and unspiked samples: a new approach. Geochemistry, Geophysics, Geosystems 5.

Lupker, M., Aciego, S., Bourdon, B., Schwander, J., Stocker, T., 2010. Isotopic tracing (Sr, Nd, $\mathrm{U}$ and $\mathrm{Hf}$ ) of continental and marine aerosols in an 18th century section of the Dye-3 ice core (Greenland). Earth and Planetary Science Letters 295, 277-286.

Mahlen, N.J., Beard, B.L., Johnson, C.M., Lapen, T.J., 2008. An investigation of dissolution methods for $\mathrm{Lu}$ - Hf and $\mathrm{Sm}$ - Nd isotope studies in zircon - and garnet - bearing whole - rock samples. Geochemistry, Geophysics, Geosystems 9.

Mahowald, N., Kohfeld, K., Hansson, M., Balkanski, Y., Harrison, S.P., Prentice, I.C., Schulz, M., Rodhe, H., 1999. Dust sources and deposition during the last glacial maximum and current 
climate: A comparison of model results with paleodata from ice cores and marine sediments. Journal of Geophysical Research: Atmospheres 104, 15895-15916.

Mahowald, N.M., Muhs, D.R., Levis, S., Rasch, P.J., Yoshioka, M., Zender, C.S., Luo, C., 2006. Change in atmospheric mineral aerosols in response to climate: Last glacial period, preindustrial, modern, and doubled carbon dioxide climates. Journal of Geophysical Research-Atmospheres 111.

Marchant, D.R., Head, J.W., 2007. Antarctic dry valleys: Microclimate zonation, variable geomorphic processes, and implications for assessing climate change on Mars. Icarus 192, 187 222.

Marino, F., Castellano, E., Ceccato, D., De Deckker, P., Delmonte, B., Ghermandi, G., Maggi, V., Petit, J.-R., Revel - Rolland, M., Udisti, R., 2008. Defining the geochemical composition of the EPICA Dome $\mathrm{C}$ ice core dust during the last glacial - interglacial cycle. Geochemistry, geophysics, geosystems 9.

Meneghel, M., Bondesan, A., Salvatore, M., Orombelli, G., 1999. A model of the glacial retreat of upper Rennick Glacier, Victoria Land, Antarctica. Annals of Glaciology 29, 225-230.

Mensing, T., Faure, G., 1996. Cretaceous alteration of Jurassic volcanic rocks, Pain Mesa, northern Victoria Land, Antarctica. Chemical geology 129, 153-161.

Meyer, I., Davies, G.R., Stuut, J.-B.W., 2011. Grain size control on Sr-Nd isotope provenance studies and impact on paleoclimate reconstructions: An example from deep-sea sediments offshore NW Africa. Geochemistry, Geophysics, Geosystems 12, Q03005.

Nowell, G., Kempton, P., Noble, S., Fitton, J., Saunders, A., Mahoney, J., Taylor, R., 1998. High precision $\mathrm{Hf}$ isotope measurements of MORB and OIB by thermal ionisation mass spectrometry: insights into the depleted mantle. Chemical Geology 149, 211-233.

Oberholzer, P., Baroni, C., Salvatore, M., Baur, H., Wieler, R., 2008. Dating late Cenozoic erosional surfaces in Victoria Land, Antarctica, with cosmogenic neon in pyroxenes. Antarctic Science 20, 89-98.

Oberholzer, P., Baroni, C., Schaefer, J.M., Orombelli, G., Ochs, S.I., Kubik, P.W., Baur, H., Wieler, R., 2003. Limited Pliocene/Pleistocene glaciation in Deep Freeze Range, northern Victoria Land, Antarctica, derived from in situ cosmogenic nuclides. Antarctic Science 15, 493502.

Orombelli, G., 1990. Holocene environmental changes at Terra Nova Bay (Victoria Land, Antarctica). Memorie della Societa Geologica Italiana 43, 145-147.

Patchett, P.J., Tatsumoto, M., 1981. A routine high-precision method for Lu-Hf isotope geochemistry and chronology. Contr. Mineral. and Petrol. 75, 263-267.

Perchiazzi, N., Folco, L., Mellini, M., 1999. Volcanic ash bands in the Frontier Mountain and Lichen Hills blue-ice fields, northern Victoria Land. Antarctic Science 11, 353-361. 
Piotrowski, A.M., Lee, D.-C., Christensen, J.N., Burton, K.W., Halliday, A.N., Hein, J.R.,

808 Günther, D., 2000. Changes in erosion and ocean circulation recorded in the Hf isotopic

809 compositions of North Atlantic and Indian Ocean ferromanganese crusts. Earth and Planetary

810 Science Letters 181, 315-325.

811 Revel-Rolland, M., De Deckker, P., Delmonte, B., Hesse, P.P., Magee, J.W., Basile-Doelsch, I., 812 Grousset, F., Bosch, D., 2006. Eastern Australia: A possible source of dust in East Antarctica 813 interglacial ice. Earth and Planetary Science Letters 249, 1-13.

814 Rocchi, S., Tonarini, S., Armienti, P., Innocenti, F., Manetti, P., 1998. Geochemical and isotopic structure of the early Palaeozoic active margin of Gondwana in northern Victoria Land,

816 Antarctica. Tectonophysics 284, 261-281.

817 Schäfer, J.M., Ivy-Ochs, S., Wieler, R., Leya, I., Baur, H., Denton, G.H., Schlüchter, C., 1999. 818 Cosmogenic noble gas studies in the oldest landscape on earth: surface exposure ages of the Dry 819 Valleys, Antarctica. Earth and Planetary Science Letters 167, 215-226.

820 Selby, M., Rains, R., Palmer, R., 1974. Eolian deposits of the ice-free Victoria Valley, southern 821 Victoria Land, Antarctica. New Zealand Journal of Geology and Geophysics 17, 543-562.

822 Sims, K.W.W., Blichert-Toft, J., Kyle, P.R., Pichat, S., Gauthier, P.-J., Blusztajn, J., Kelly, P., 823 Ball, L., Layne, G., 2008. A Sr, Nd, Hf, and $\mathrm{Pb}$ isotope perspective on the genesis and long-term 824 evolution of alkaline magmas from Erebus volcano, Antarctica. Journal of Volcanology and 825 Geothermal Research 177, 606-618.

Stevenson, E.I., Hermoso, M., Rickaby, R.E., Tyler, J.J., Minoletti, F., Parkinson, I.J., Mokadem, F., Burton, K.W., 2014. Controls on stable strontium isotope fractionation in coccolithophores with implications for the marine Sr cycle. Geochimica et cosmochimica acta 128, 225-235.

Strasky, S., Di Nicola, L., Baroni, C., Salvatore, M.C., Baur, H., Kubik, P.W., Schlüchter, C., Wieler, R., 2009. Surface exposure ages imply multiple low-amplitude Pleistocene variations in East Antarctic ice sheet, Ricker Hills, Victoria Land. Antarctic Science 21, 59-69.

Stuiver, M., Denton, G.H., Hughes, T.J., Fastook, J.L., 1981. History of the marine ice sheet in 436.

837 Sugden, D., Denton, G., 2004. Cenozoic landscape evolution of the Convoy Range to Mackay 838 Glacier area, Transantarctic Mountains: onshore to offshore synthesis. Geological Society of 839 America Bulletin 116, 840-857.

840 Sugden, D.E., McCulloch, R.D., Bory, A.J.M., Hein, A.S., 2009. Influence of Patagonian 841 glaciers on Antarctic dust deposition during the last glacial period. Nature Geoscience 2, 281842285. 
843 Sugden, D.E., Summerfield, M.A., Denton, G.H., Wilch, T.I., McIntosh, W.C., Marchant, D.R., 844 Rutford, R.H., 1999. Landscape development in the Royal Society Range, southern Victoria

845 Land, Antarctica: stability since the mid-Miocene. Geomorphology 28, 181-200.

846 Summerfield, M., Sugden, D., Denton, G., Marchant, D., Cockburn, H., Stuart, F., 1999.

847 Cosmogenic isotope data support previous evidence of extremely low rates of denudation in the

848 Dry Valleys region, southern Victoria Land, Antarctica. Geological Society, London, Special

849 Publications 162, 255-267.

850 Svensson, A., Biscaye, P.E., Grousset, F.E., 2000. Characterization of late glacial continental 851 dust in the Greenland Ice Core Project ice core. Journal of Geophysical Research: Atmospheres $852105,4637-4656$.

853 Vallelonga, P., Gabrielli, P., Balliana, E., Wegner, A., Delmonte, B., Turetta, C., Burton, G., 854 Vanhaecke, F., Rosman, K.J.R., Hong, S., Boutron, C.F., Cescon, P., Barbante, C., 2010. Lead 855 isotopic compositions in the EPICA Dome C ice core and Southern Hemisphere Potential Source 856 Areas. Quaternary Science Reviews 29, 247-255.

857 van de Flierdt, T., Goldstein, S.L., Hemming, S.R., Roy, M., Frank, M., Halliday, A.N., 2007. 858 Global neodymium-hafnium isotope systematics — revisited. Earth and Planetary Science 859 Letters 259, 432-441.

860 Vervoort, J.D., Blichert-Toft, J., 1999. Evolution of the depleted mantle: Hf isotope evidence 861 from juvenile rocks through time. Geochimica et Cosmochimica Acta 63, 533-556.

862 Vervoort, J.D., Patchett, P.J., Blichert-Toft, J., Albarède, F., 1999. Relationships between Lu-Hf 863 and $\mathrm{Sm}-\mathrm{Nd}$ isotopic systems in the global sedimentary system. Earth and Planetary Science 864 Letters 168, 79-99.

865 Zhao, W., Sun, Y., Balsam, W., Lu, H., Liu, L., Chen, J., Ji, J., 2014. Hf-Nd isotopic variability 866 in mineral dust from Chinese and Mongolian deserts: implications for sources and dispersal.

867 Scientific reports 4.

868

869 